Annales Missiologici Posnanienses t. 20 (2015), s. 55-69

DOI: $10.14746 / \mathrm{amp} .2015 .20 .5$

ZBIGNIEW S. PAWŁOWSKI

Uniwersytet Medyczny w Poznaniu / Poznań University of Medical Sciences

\title{
Pomoc dla misyjnych ośrodków medycznych na tle globalnej ochrony zdrowia
}

Od najdawniejszych czasów uzdrawianie chorych przypisywano siłom nadprzyrodzonym i wiązano $\mathrm{z}$ religią. Przedstawiana w Ewangelii samarytańska opieka nad chorym jest trwałym wzorem najważniejszego przykazania religii chrześcijańskiej - miłości bliźniego. Już I-IV w. pomoc Kościoła dla współbraci potrzebujących obejmowano terminem diakonia. Z czasem wyspecjalizowała się ona w takie działy, jak: opieka szpitalna, opieka nad sierotami i dziećmi porzuconymi, opieka nad starcami, hospicja dla biednych oraz dla pielgrzymów i wędrujących („Proceedings”; Medicus Mundi Polonia).

W czasach kolonialnych w XIX w. i w pierwszej połowie XX w. za wzorem dr. Alberta Schweitzera w krajach misyjnych powstało wiele chrześcijańskich ośrodków medycznych ofiarujących pomoc chorym, zwłaszcza w peryferyjnych rejonach świata (Woy-Wojciechowski, Magowska). Szczególną opieką otaczano trędowatych, którzy byli marginalizowaną i odseparowywaną częścią lokalnych społeczności. Niezależnie od setek i tysięcy polskich misjonarek i misjonarzy, świadczących ofiarnie pomoc medyczną, działało wówczas wiele świetlanych postaci, które zapisały się złotymi zgłoskami w dziejach polskiej misjologii. Należą do nich bł. Jan Beyzym, działający na przełomie XIX/XX w., a współcześnie o. Marian Żelazek oraz dr h.c. Wanda Błeńska (Molewska i Pawelec, Pietraszek). Dzieła życia tych dwojga wspomnianych osób, które dziesiątki lat pracowały w Puri w Indiach i w Bulubie w Ugandzie, prowadzone są dzisiaj przez miejscowych lekarzy lub misjonarzy.

Z końcem ery kolonialnej dla misji chrześcijańskich, obok działania ewangelizującego, niezwykle ważna stała się pomoc medyczna, charytatywna i edukacyjna niezamożnym peryferyjnym społecznościom powstających nowych samodzielnych już krajów. Był to okres wzmożonej ekspansji i rozwoju 
medycznych ośrodków misyjnych, również ze strony polskiej, mimo trudności stwarzanych przez ówczesne władze. Jednakże rola pomocy medycznej świadczonej przez instytucje religijne poczęła zmieniać się w miarę rozwoju międzynarodowych agend zdrowia publicznego i powstawania tzw. global health.

Zadaniem poniższego artykułu jest przedstawienie problemów, jakie dla misyjnych ośrodków medycznych wynikają z szerokiego zaangażowania się $\mathrm{w}$ ochronę zdrowia wielu instytucji niereligijnych i usamodzielniania się tzw. krajów misyjnych. Proponowane są aktualne zasady pomocy z Polski udzielanej misyjnym ośrodkom medycznym.

\section{Zdrowie dla wszystkich i rola instytucji religijnych w jego osiąganiu}

Przez długi czas stan zdrowia ludzkiej populacji był niedoceniany, gdyż uważano, że znaczna śmiertelność, zwłaszcza dzieci do lat pięciu, jest czynnikiem przeciwdziałającym przeludnieniu kuli ziemskiej. Dopiero w drugiej połowie lat siedemdziesiątych XX w. wśród ówczesnych elit zdrowia publicznego zaczęła dojrzewać idea „zdrowia dla wszystkich” i prawa każdego człowieka do ochrony jego zdrowia (Pawłowski „Zdrowie”). Tym samym troska o zdrowie ludzi w świecie została $\mathrm{w}$ dużej części przerzucona na instytucje międzynarodowe, jak WHO - Światową Organizację Zdrowia czy UNICEF - Fundusz Narodów Zjednoczonych na Rzecz Dzieci, a także rządowe (Pawłowski „Światowa Organizacja Zdrowia”). W tej sytuacji rola religijnych pozarządowych instytucji zajmujących się zdrowiem zmniejszyła się, a znaczna część dotychczasowego charytatywnego wsparcia światowego przestała być adresowana do misji chrześcijańskich jako głównego odbiorcy. Od tej pory zaczęły też powstawać liczne, niezwiązane z religią, organizacje rządowe i pozarządowe przeznaczające duże sumy na ściśle kontrolowane programy prozdrowotne, głównie na zwalczanie AIDS, malarii, gruźlicy oraz opiekę nad matką i dzieckiem.

Światowy brak kadr medycznych i paramedycznych spowodował jednak, że zaczęto ponownie brać pod uwagę istniejący potencjał instytucji religijnych - faith institutions, jako istotny społeczny, profesjonalny i liczbowo ważny czynnik w szeroko pojętej globalnej ochronie zdrowia (Levin). Ruch ten zapoczątkował prezydent Jimmy Carter w roku 1996, powołując tzw. partnerstwo publiczno-prywatne w ochronie zdrowia. Prezydent George W. Bush nadał mu w roku 2001 formy prawne w formie White House-Based Office \& Neighbourhood Partnership, a później, w roku 2003, tworząc światowy program pomocy chorym na AIDS, działający do dziś. Współpraca publiczno-prywatna opierała się na działaniach mających na celu: zmianę ludzkich zachowań, edukację prozdrowotną, ochronę środowiska, wprowadzanie pozytywnych 
zmian prawnych w polityce ochrony zdrowia. Opierała się ona w dużej mierze na wolontariacie, np. Peace Corps, oraz działaniu filantropijnym i misyjnym, prowadzącym do znacznego wzmacniania lokalnych struktur społecznych community health.

\section{Działania ekumeniczne}

Jesteśmy przyzwyczajeni spostrzegać działania ekumeniczne z perspektywy Kościoła katolickiego. Tymczasem już w połowie lat 1900. w wieloreligijnej społeczności USA działalność instytucji religijnych przyjęła charakter ekumeniczny i uzyskiwała poparcie rządu, o ile - zgodnie z tamtejszą konstytucją - nie dążyła do popierania tylko jednego wyznania.

Wśród międzynarodowych organizacji dopiero w roku 2008 ukazał się dokument WHO dotyczący współpracy tej organizacji z medycznymi instytucjami religijnymi w tworzeniu podstawowej opieki medycznej (Building from common Foundations).

W chrześcijańskiej Europie pewną pomocą w rozwoju ośrodków misyjnych stały się działania ekumeniczne korzystające z doświadczenia bogatszych i lepiej zorganizowanych misji protestanckich. Agendy Światowej Rady Kościołów prowadzi od wielu lat Ecumenic Center w Genewie.

Duże znaczenie w ekumenizacji opieki zdrowotnej miały też konferencje regularnie organizowane przez Papieskie Biuro ds. Zdrowia w Watykanie i publikowane na łamach Dolentium Hominum. Streszczenia tych watykańskich konferencji omawiających, obok chrześcijańskiego podejścia do wybranych problemów medycznych, również stanowisko $\mathrm{w}$ tej mierze środowisk islamskich, buddyjskich i judaistycznych, były często referowane na łamach Medicus Mundi Polonia („Posługa lecznicza Kościoła”). Działalność, założonego przez Jana Pawła II Papieskiego Biura ds. Zdrowia, koordynującego działania krajowych episkopatów w zakresie ochrony zdrowia, wymaga jednakże oddzielnego opracowania, gdyż dotyczy nie tylko zagadnień stricte medycznych, ale również spraw zdrowia na szerokiej płaszczyźnie norm moralnych i ewangelizującego działania Kościoła powszechnego.

\section{Milenijne cele rozwoju}

Na przełomie XX i XXI w. czynniki ekonomiczne zaczęły odgrywać coraz większą rolę w rozwoju gospodarki światowej. Docenianie w większym stopniu przez elity polityczne promocji zdrowotności, edukacji oraz ochrony środowiska dla ogólnego rozwoju ekonomicznego znalazło swój wyraz w uchwa- 
lonej w roku 2000 przez przedstawicieli 189 państw należących do Narodów Zjednoczonych deklaracji o tzw. milenijnych celach rozwoju (Pawłowski, „Millenium”). Wśród 10 zadań, przewidzianych do realizacji w ciągu 15 lat było: obniżenie o połowę liczby ludzi żyjących za mniej niż 1 USD dziennie, obniżenie o połowę liczby ludzi głodnych w świecie, zabezpieczenie pełnego kursu podstawowej edukacji dziewczętom i chłopcom na całym świecie, wyrównanie dostępu dziewcząt do edukacji, również na wyższych poziomach, zredukowanie o $2 / 3$ odsetka dzieci nieprzeżywających piątego roku życia, obniżenie 0 3/4 liczby zgonów kobiet rodzących, zwalczanie malarii, gruźlicy, AIDS, ochrona środowiska, w tym zapewnienie swobodnego dostępu do wody, promocja współpracy międzynarodowej w zakresie gospodarczym, finansowym i swobodnej wymiany doświadczeń, dotyczących wszechstronnego rozwoju.

Po 15 latach działania programu odnotowano pewną poprawę w ochronie życia dzieci do pięciu lat i w zwalczaniu malarii, gruźlicy i AIDS. Przeszkodą w rozwoju ochrony zdrowia i edukacji jest znaczny brak lekarzy i nauczycieli. Rozwijający się terroryzm bardzo utrudnia dążenie do wyrównanego rozwoju świata. Obecnie duży nacisk kładzie się na wzajemną solidarność i partnerstwo w działaniach, zwłaszcza tych, które dotyczą peryferyjnych rejonów świata i zaniedbanych społeczności.

\section{Globalna ochrona zdrowia}

Wytyczenie i realizacja milenijnych celów rozwoju zapoczątkowało również szereg działań objętych ogólną nazwą global health (Brown, Cueto i Fee). Do ich powstania niezależnie od „ekonomicznej” globalizacji przyczyniło się pojawienie groźnych epidemii, np. dengi na kontynencie południowoamerykańskim, SARS - ciężkiego ostrego zespołu oddechowego, grypy wywołanej szczepami odzwierzęcymi, a ostatnio zakażenia wirusem ebola, przekraczających granice państw dzięki gwałtownemu rozwojowi międzynarodowej komunikacji. Zagrożenie państw zamożnych masowymi zachorowaniami na mało znane infekcje wirusowe zmusiło je nie tylko do uszczelnienia swoich granic, ale też do próby likwidacji ognisk epidemii na odległych kontynentach (Pawłowski, „Ebola!”). Niezależnie od instytucji zajmujących się zdrowiem międzynarodowym, m.in. WHO oraz CDC, czyli Centrum Zwalczania Chorób w Atlancie, powstał szereg organizacji zajmujących się ochroną zdrowia $\mathrm{w}$ ujęciu globalnym lub wspierających ją, brak im jednakże koordynacji w skali światowej. Powodem tego jest złożoność wielorakich czynników determinujących poziom zdrowotności społeczeństw: socjalnych, ekonomicznych, środowiskowych i politycznych (Missioni). Nie zanosi się na to, aby 
wpływ tych czynników na zdrowie globalne został w najbliższej przyszłości skutecznie korygowany „od góry”, na poziomie międzynarodowym. Pozostaje więc ochrona zdrowia na poziomie podstawowym, wśród zainteresowanych małych społeczności. Tu dużego znaczenia nabierają prozdrowotne działania misji religijnych, zwłaszcza tych, które dysponują ośrodkami medycznymi.

\section{Konieczność współdziałania instytucji religijnych w zakresie ochrony zdrowia}

Skuteczna likwidacja ospy prawdziwej w roku 1980 wykazała realną możliwość opanowania dzięki wspólnemu międzynarodowemu wysiłkowi jednej z najgroźniejszych chorób zakaźnych. Podsyciła ona „globalny” wymiar ochrony zdrowia. W kolejce do całkowitej likwidacji czeka choroba Heinego-Medina, tj. poliomyelitis, oraz drakunkuloza. Wspólnym wysiłkiem znaczny postęp uzyskano w opiece nad dziećmi do lat pięciu i w zwalczaniu trądu. Odnotowano też znaczący postęp w opanowywaniu AIDS, gruźlicy, malarii, jakkolwiek daleko od ich likwidacji. Inicjatywę zwalczania niedocenianych do tej pory chorób tropikalnych (Neglected tropical deseases) podjęło WHO. Została ona szeroko poparta przez niektóre instytucje rządowe, jak np. USAID - Amerykańską Agencję dla Międzynarodowego Rozwoju oraz organizacje pozarządowe, np. przez bogatą fundację Billa i Melindy Gatesów. Poza badaniami naukowymi, mającymi na celu bliższe poznanie dróg szerzenia się i patologii niektórych często występujących chorób tropikalnych, opracowano też uproszczone schematy ich rozpoznawania, leczenia i prewencji. Ich skuteczność zależy od jednolitego i równoczesnego stosowania przez wszystkie istniejące rządowe i pozarządowe ośrodki zdrowia. I tu pojawił się konflikt między instytucjami rządowymi, formalnie odpowiedzialnymi za wdrażanie ogólnie przyjętych programów zdrowotnych, a misyjnymi ośrodkami zdrowia, które uważały pewne ich elementy (np. szerokie korzystanie z prezerwatyw) za niezgodne z obowiązującymi w nich normami moralnymi. W tym konflikcie pewna niezależność medycznych ośrodków misyjnych wobec programów rządowych często powodowała ich lekceważenie i subwencjonowanie niewspółmiernie małe wobec ich codziennych zadań wykonywanych w lokalnej ochronie zdrowia (Pawłowski, „Tożsamość katolickich instytucji”).

Zwykle niedoceniana jest rola misji we wzmacnianiu więzi społecznych, które są nader przydatne nie tylko w czasie epidemii i w przypadku innych klęsk żywiołowych. Jednakże w czasie niektórych epidemii włączenie się misji, polegające na gromadzeniu wiernych na nabożeństwach lub pogrzebach, jest niewskazane, jak np. w czasie ostatniej epidemii eboli w Afryce. 


\section{Poprawa standardów działania misyjnych ośrodków medycznych}

Wzajemna współpraca w zakresie ochrony zdrowia wymaga nie tylko obustronnych kompromisów, ale również dostosowania misyjnych ośrodków medycznych do standardów międzynarodowych, zarówno pod względem fachowym, jak i menadżerskim. Po roku 2000 Medicus Mundi International (MMI), instytucja powstała w roku 1969 z inicjatywy belgijskich lekarzy i biskupów (Widmer), podjęła próby „unowocześniania” afrykańskich medycznych ośrodków misyjnych. Propozycje w tej sprawie przedstawiono na kolejnych konferencjach angielskojęzycznych episkopatów w roku 2004 w Kampali oraz frankofońskich w roku 2006 w Cotonou. W latach następnych zorganizowano dodatkowo dwa następne spotkania w roku 2007 w Dar es Saalam dla episkopatu tanzańskiego i w roku 2008 w Bangui dla episkopatów sześciu krajów centralnej Afryki. Rezultaty spotkań były opisane w periodyku „Medicus Mundi Polonia” (,Posługa lecznicza Kościoła”).

Sugestie MMI dotyczyły: (a) redefinicji posługi leczniczej Kościoła prowadzonej przez odpowiednie episkopaty, (b) odgórnej akceptacji nowoczesnego systemu prowadzenia misyjnych ośrodków medycznych, nawiązującego m.in. do relacji z instytucjami rządowymi i kontraktowania usług oraz (c) poinformowania ośrodków misyjnych o potrzebie zmian i pomocy w ich wprowadzeniu. Medicus Mundi International oferował swoje doświadczenie w usprawnieniu działania ośrodków w zakresie podstawowej opieki medycznej oraz dostarczenie odpowiednich narzędzi do prowadzenia tej nowoczesnej działalności.

W roku 2009 MMI zleciło Instytutowi Misyjnemu w Würzburgu krytyczne podsumowanie wysiłków MMI w zakresie pomocy medycznym ośrodkom misyjnym, a w szczególności w strategicznej restrukturyzacji ich działalności wobec dokonujących się procesów globalizacji w świecie. Badania te zostały podsumowane w dokumencie Survey on the results of Medicus Mundi International's involvement in catholic Bishops conferences since 2000 opublikowanym przez Medical Mission Institute w Würzburgu w 2010 r. (Pawłowski, „Raport Instytutu Misyjnego”). Wyniki tych badań nie były zachęcające, gdyż wykazały, że na kilkadziesiąt episkopatów tylko kilka, tj. Tanzanii, Ugandy, Ghany, Zambii i Malawi, wprowadziło istotne zmiany w pozycji i strategii agend medycznych Kościoła misyjnego w Afryce. W tej sytuacji MMI doszedł do wniosku, że w najbliższych latach nie może skutecznie pomóc katolickim instytucjom prowadzącym posługę leczniczą na tym kontynencie. 


\section{Reorganizacja pracy medycznych ośrodków raczej lokalna niż odgórna}

Starania MMI w Afryce nie minęły jednakże bez echa. Biskup Aloysius Balina stwierdził, że episkopat tanzański przygotowuje nową wersję zaleceń polegającą na tym, że poszczególne diecezje mają opracować własny plan działania skorelowany z planami rządowymi. Tu należałoby wspomnieć, że Fundacja Redemptoris Missio z Poznania zaangażowała się w latach 2001-2007 w stworzenie w Kiabakari w Tanzanii nowoczesnego ośrodka zdrowia (ACHAP, Hotline Human Resources for Health), który obecnie wdraża podstawową opiekę medyczną na podległym mu rejonie już samodzielnie bez pomocy Fundacji. Okazało się, że wszelkie działania w terenie powinny być dostosowane do lokalnych sytuacji i trudno nimi kierować z oddali. Stąd istotne znaczenie $\mathrm{w}$ dostosowywaniu potencjalnej roli misyjnych ośrodków medycznych w ochronie zdrowia zaczęły coraz sprawniej odgrywać lokalne Chrześcijańskie Towarzystwa Medyczne obejmujące większość kontynentu afrykańskiego, co ukazuje mapa nr 1. Zyskały one znaczne poparcie ze strony USA jako włączone pod skrzydła organizacji USAID - Capacity Plus. Wydają miesięcznik Hotline Human Resources for Health będący szerokim przeglądem działań organizacyjnych dotyczących ochrony zdrowia na kontynencie afrykańskim. Capacity Plus skutecznie objął swoją opieką misyjne ośrodki medyczne w zakresie pomocy personalnej (szkolenia), wyposażenia i nowoczesnego prowadzenia terenowej instytucji medycznej.

W tej sytuacji MMI nawiązał bliższe kontakty z lokalnymi chrześcijańskimi towarzystwami lekarskimi w Afryce, prowadzonymi przez młodą kadrę miejscowych lekarzy, która przygotowuje się do tego, aby wziąć w swoje ręce ochronę zdrowia we własnych krajach. Stopniowo afrykańskie towarzystwa medyczne stają się liczącą się organizacją kadr medycznych krajów rozwijających się i aktywnym współpracownikiem narodowych resortów zdrowia.

\section{Chrześcijańskie ośrodki medyczne w Nigerii, Kenii i Tanzanii}

Trudno jest ocenić rozmiar pomocy religijnych ośrodków medycznych w świecie. W Afryce waha się on od 4\% w Angoli do 35\% w Ruandzie (Kagawa, Anglemyer i Montagu). Ze sprawozdania Afrykańskiego Towarzystwa Medycznego z 2014 r. (African Christian Health Associations Platform) warto przytoczyć bardziej szczegółowe dane dotyczące trzech dużych państw afrykańskich: Nigerii, Kenii oraz Tanzanii.

Christian Health Association of Nigeria - CHAN powstała w roku 1973 z inicjatywy episkopatu katolickich biskupów nigeryjskich. Głównym jej zadaniem jest utrzymanie opieki medycznej na terenach peryferyjnych Nigerii. 


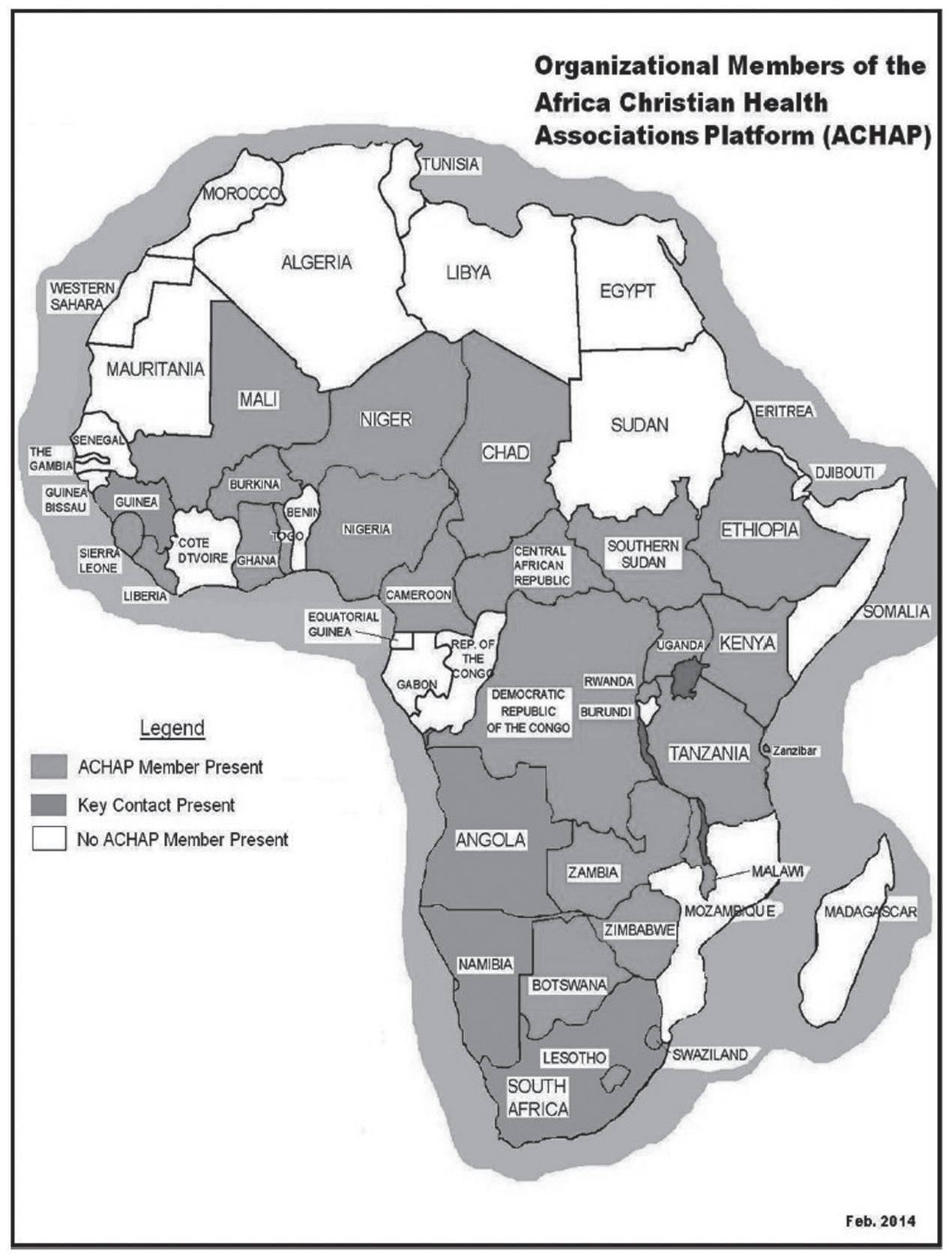

Mapa nr 1. Państwa zrzeszone w ramach Africa Christian Health Association Platform (ACHAP). Źródło: ACHAP, Hotline Human Resources for Health, nr 94, September 2014, p. 2. Wykorzystano za pozwoleniem ACHAP / used with permission of ACHAP. 


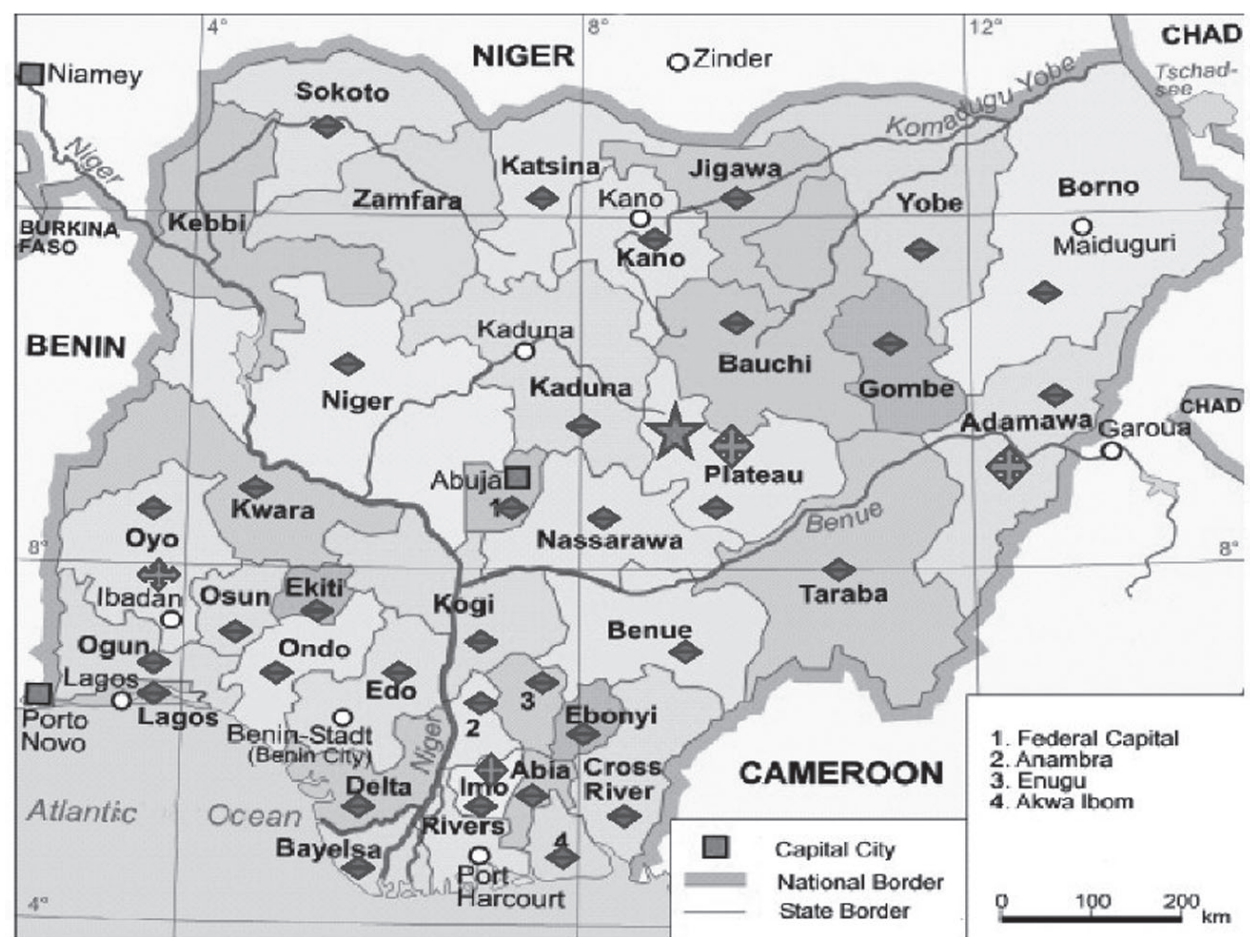

\section{KEY}

\begin{tabular}{|l|l|}
\hline $\begin{array}{l}\text { CHAN Headquar- } \\
\text { ter- Jos, Plateau } \\
\text { State }\end{array}$ \\
\hline $\begin{array}{l}\text { CHAN Regional } \\
\text { Offices -Adama- } \\
\text { wa (Zone A), } \\
\text { Plateau (Zone } \\
\text { B), Imo (Zone B) } \\
\text { and Oyo (Zone C) } \\
\text { States }\end{array}$ \\
\hline $\begin{array}{l}\text { States with } \\
\text { CHAN Member } \\
\text { institutions }\end{array}$ \\
\hline
\end{tabular}

Mapa nr 2. Struktura organizacyjna Christian Health Association w Nigerii (CHAN). Źródło: ACHAP, Hotline Human Resources for Health, nr 95, October 2014, p. 6. Wykorzystano za pozwoleniem ACHAP / used with permission of ACHAP. 


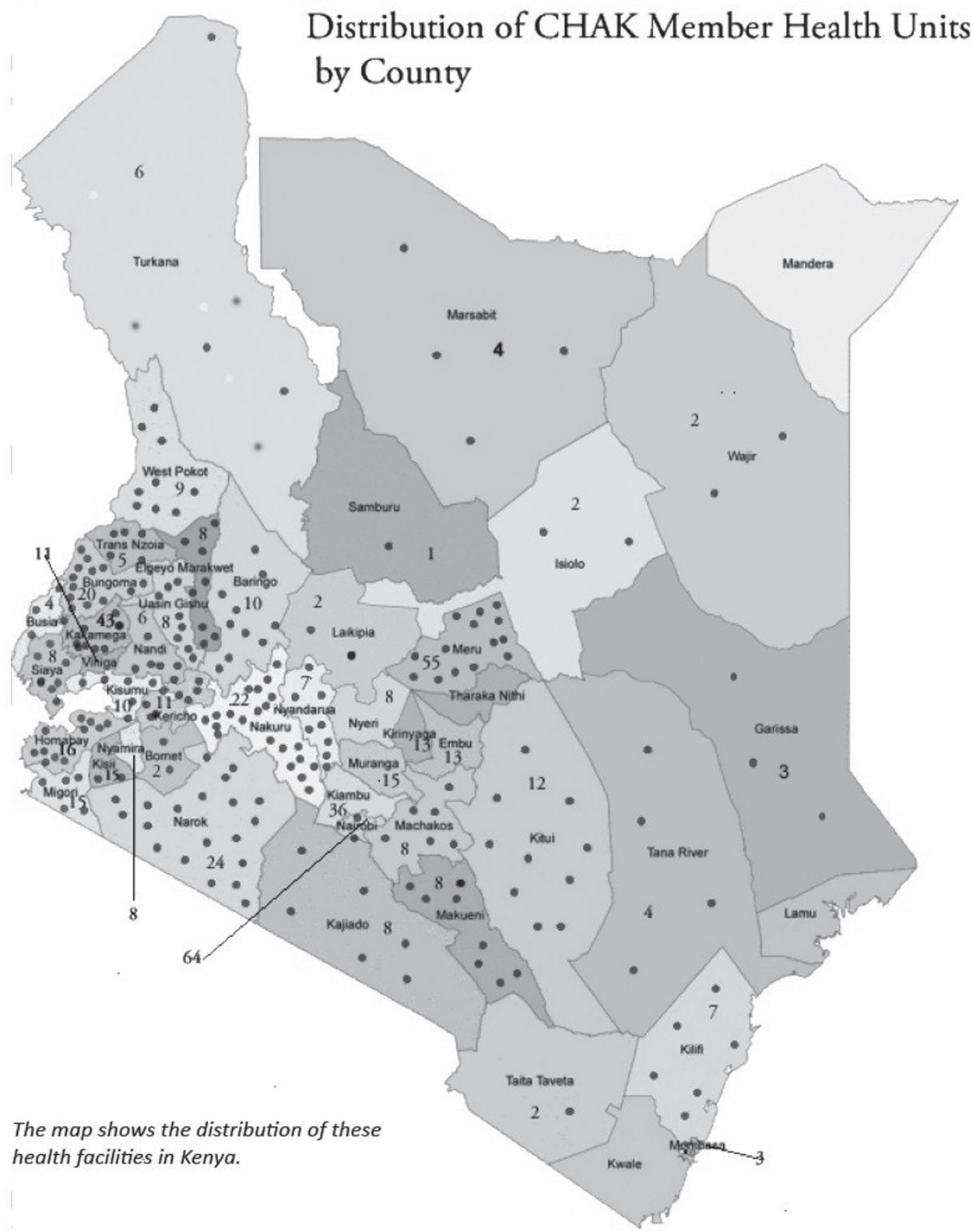

Mapa nr 3. Struktura organizacyjna Christian Health Association w Kenii (CHAK). Źródło: ACHAP, Hotline Human Resources for Health, nr 94, September 2014, p. 4. Wykorzystano za pozwoleniem ACHAP / used with permission of ACHAP. 
Swoim oddziaływaniem CHAN obejmuje ponad 500 chrześcijańskich instytucji, w tym 350 ośrodków misyjnych, 60 instytucji edukacyjnych - trzy kolegia medyczne, trzy kolegia technologii medycznych, 10 szkół laboratoryjnych, 21 szkół pielęgniarskich i 16 szkół położnych, co ukazuje mapa $\mathrm{nr} 2$. Są to w 59\% ośrodki protestanckie i w $41 \%$ katolickie. Ocenia się, że CHAN otacza opieką $40 \%$ populacji nigeryjskiej. Organizacja ta jest prowadzona przez lekarzy nigeryjskich, sekretariat medyczny liczy 27 etatów, a farmaceutyczny 72 , ma także doskonałe relacje z nigeryjskim ministerstwem zdrowia. Warto wspomnieć, że dzięki szybkiej i fachowej działalności służby zdrowia w Nigerii nie doszło tam ostatnio do rozszerzenia się epidemii eboli, mimo 20 zawleczonych przypadków, w tym ośmiu śmiertelnych.

Christian Health Association of Kenya - CHAK powstało w latach trzydziestych XX w. W latach 1946-1982 ograniczało swoją działalność do ośrodków protestanckich, ale później powróciło do konwencji ekumenicznej, obecnie obejmującej również instytucje muzułmańskie. W roku 2010 stowarzyszenie to liczyło 563 członków, wśród nich 23 szpitale, 53 ośrodki zdrowia, 364 dyspensaria, 58 organizacji kościelnych, 24 organizacje społeczne oraz 10 szkół pielęgniarek i położnych. Załączona mapa nr 3 przedstawia rozmieszczenie członków CHAK w Kenii. Organizacja ta ma bardzo dobre relacje z ministerstwem zdrowia, dba o godziwe sponsorowanie religijnych ośrodków zdrowia, ich wyposażenie, utrzymanie sprzętu, w tym elektronicznego, prowadzenie ich w sposób ekonomiczny, kontakty z organizacjami i programami międzynarodowymi. Przykładem dobrej współpracy rządu i instytucji misyjnej w Kenii jest nowoczesny Kikuyu Mission Hospital, założony w roku 1908 przez szkockiego misjonarza prezbiteriańskiego.

W Tanzanii w 1992 roku powstało Christian Council of Tanzania-CCT, promujące opiekę medyczną i edukację w porozumieniu z rządem, organizacjami pozarządowymi i innymi międzynarodowymi instytucjami rozwojowymi. Swoją działalnością CCT obejmuje 102 szpitale, 101 centrów szpitalnych, 697 dyspensariów - razem 13,7\% instytucji medycznych w Tanzanii. Ponad to CCT oferuje szeroką działalność edukacyjną. Ma pod opieką 58 centrów szkolenia, 136 szkół podstawowych i 308 ponadpodstawowych, 51 seminariów, 126 szkół zawodowych, 47 college’ów, w tym 33 uniwersyteckie.

\section{Podsumowanie i wnioski odnośnie do pomocy medycznej krajom misyjnym}

Niemożliwe jest bezpośrednie włączenie znacznego potencjału religijnych medycznych ośrodków misyjnych do działań globalnej opieki medycznej prowadzonych przez świeckie organizacje międzynarodowe. Każde porozu- 
mienie pozostaje na papierze chociażby $\mathrm{z}$ tego powodu, że w każdym kraju sytuacja przedstawia się odmiennie i nie wszystkie odgórne zalecenia można z powodzeniem zaadaptować do miejscowych potrzeb. Konkretny postęp w tym zakresie może być osiągnięty raczej na podstawie lokalnych porozumień, opartych na kompromisach łatwiejszych do zrozumienia i przyjęcia przez miejscowych rządowych partnerów i lokalne episkopaty, aniżeli na podstawie sugestii odległych ponadnarodowych instytucji, mimo że wielokrotnie zasługują one na rozważenie. Dotyczy to zwłaszcza opracowywanych centralnie standardów rozpoznawania i leczenia chorób tropikalnych.

W tej sytuacji polska zdalna pomoc medycznym ośrodkom misyjnym w utrzymaniu ich ważnego partnerstwa w światowej, globalnej, ochronie zdrowia winna polegać na:

1) Przekonywaniu misjonarzy, że oferowana pomoc medyczna i edukacyjna jest istotnym elementem skutecznej ewangelizacji i zbliża społeczności do Kościoła. Obecnie może być w pełni realizowana tylko przy współpracy z organizacjami rządowymi i pozarządowymi realizującymi program global health. Zachowanie przy tym „tożsamości” religijnej misji może wymagać umiejętnych negocjacji i pewnych lokalnych kompromisów.

2) Ważna jest świadomość, że póki co działamy jako „obcy” w warunkach odmiennych etnograficznie, środowiskowo, socjologicznie, ale nadchodzi czas, kiedy opieka medyczna w krajach misyjnych będzie świadczona w coraz większym stopniu przez miejscowy personel medyczny i paramedyczny; istotnym naszym zadaniem jest stopniowo go do tych zadań przygotowywać.

3) Wobec znacznego postępu wiedzy medycznej i popularyzacji nowych technologii menażerskich istotne jest, aby misyjne ośrodki medyczne były możliwie dobrze wyposażone $\mathrm{w}$ nowoczesny sprzęt, zaopatrzone w podstawowe leki i środki diagnostyczne oraz sprawnie zarządzane. Zwłaszcza ten ostatni element nie zawsze jest doceniany.

4) Pomoc z zewnątrz powinna mieć cztery wymiary:

a) Pierwszy i najważniejszy to bieżąca łączność z personelem misyjnym wyrażająca się we wszelkim możliwym poparciu dla jego pracy w trudnych warunkach i zmniejszająca jego poczucie odosobnienia.

b) Niezwykle ważny jest drugi wymiar - dbałość o zdrowie misjonarek i misjonarzy poprzez szkolenie $\mathrm{w}$ zakresie profilaktyki tropikalnej, okresowe badanie stanu zdrowia i pomoc $\mathrm{w}$ razie zachorowania.

c) Pomoc personalna, wyrażająca się w kierowaniu na misje lekarzy i studentów, nawet na kilkutygodniowe pobyty, bywa ona często doceniana jako dodatkowa ,para rąk” i źródło wiedzy medycznej.

d) Ostatnią, a chyba najczęściej stosowaną tradycyjną formą pomocy jest zaopatrzenie w brakujący sprzęt medyczny oraz niezbędne leki i materiały. 
Fundacja Redemptoris Missio wraz z Kliniką Chorób Tropikalnych i Pasożytniczych Uniwersytetu Medycznego w Poznaniu starają się realizować pomoc dla misji medycznych w krajach rozwijających się w wyżej wymieniony wszechstronny sposób (Borucka).

Ponaddwudziestoletnie doświadczenie Fundacji Redemptoris Missio w Poznaniu pokazuje, że istotną sprawą jest, aby pomoc materialna była oferowana w sposób racjonalny, przede wszystkim zgodny z potrzebami ośrodków misyjnych. Łatwiej jest organizować pomoc wybranym programom i znanym jednostkom misyjnym. Jasno określone programy takie jak: „Puszka dla Maluszka” (zakup inkubatorów), „Ołówek dla Szkoły”, „Stypendium dla Dziecka”, „Studnia dla Społeczności” są bardziej atrakcyjne dla sponsorów oraz konkretne i łatwiejsze do prowadzenia i sprawdzenia w terenie.

Przy adresowaniu pomocy wskazane jest korzystanie z pośrednictwa zgromadzeń misyjnych. Są one dokładniej zorientowane w potrzebach ośrodków misyjnych i dają rękojmię, że oferowana pomoc zostanie odpowiednio wykorzystana. Wspieranie indywidualnych misji, prowadzonych np. przez księży Fidei Donum, jest znacznie trudniejsze, chociażby z uwagi na ich formalnie luźniejszy i bardziej tymczasowy związek z misjami. Wiele jednakże zależy od osobowości człowieka korzystającego z pomocy, łatwości kontaktu z nim i efektywnej współpracy.

Z drugiej strony - jak obserwowano w czasie wieloletniej pracy Fundacji Redemptoris Missio w Poznaniu - wolontariat studentów i lekarzy w medycznych ośrodkach misyjnych ma wysoce pozytywny wpływ na ich formację osobistą i zawodową. Kontakt z prawdziwą biedą w krajach misyjnych i spontaniczność podziękowania za oferowaną pomoc zostawiają swój ślad na ich całe późniejsze życie zawodowe (Borucka).

\author{
SUPPORT OF MISSIONARY MEDICAL CENTERS \\ IN THE CONTEXT OF GLOBAL HEALTH INITIATIVES
}

\begin{abstract}
SUMMARY
Intensive development of global health programs causes some changes in the way health care and prevention is offered by the medical centers at the religious missions. Faith-based institutions still play an important role of the health care, especially in the peripheral poor human societies. However, the successful cooperation with the national health service authorities requires some compromises, mainly due to the specific identity of faith-based institutions. This is especially true for the implementation of some international standards of the modern diagnosis, treatment and prevention of
\end{abstract}


the neglected tropical diseases. The global rational directives may not always be directly adapted to the local situations and emotions in the culturally different societies in the underdeveloped world. Therefore the role of the national medical associations and local episcopates remains very essential. The progress in the medical sciences, care and prevention requires well equipped and managed missionary health and education centers.

The outside help to medical missionary centers will continue to be necessary for a long time until the developing countries would be able to handle their health problems themselves. Over twenty years of experience of the Redemptoris Missio Foundation in Poznan, Poland in supporting medical centers at the Catholic missions is presented.

Słowa kluczowe: pomoc medycznym ośrodkom misyjnym, wzrastająca globalna ochrona zdrowia, współpraca ośrodków misyjnych i instytucji rządowych

Keywords: help to missionary medical centers, increasing global health care, cooperation between missionary medical centers and the national health care institutions

\section{BIBLIOGRAFIA}

ACHAP. Hotline Human Resources for Health, nr 95, October 2014.

Borucka, Monika. „Działalność Fundacji Pomocy Humanitarnej Redemptoris Missio odpowiedzią na wyzwanie encykliki Jana Pawła II." Annales Missiologici Posnanienses 18 (2012): 187-208 .

Brown, Theodore M. Cueto, Marcos. Fee, Elizabeth. „The World Health Organization and the transition from 'international' to 'global' public health." American journal of public health 96.1 (2006): 62-72.

Building from common Foundations. World Health Organization and Faith-Based Organizations in Primary Health Care. Red. Ted Karpf, Alex Ross. Geneva: Geneva Global Performance Philanthropy and World Health Organization, 2008.

Kagawa, Rose Kalnin. Anglemyer, Andrew. Montagu, Dominic. „The Scale of Faith Based Organization Participation in Health Service Delivery in Developing Countries: Systemic Review and Meta-Analysis." PLOS ONE (2012). doi: 10.1371/journal.pone.0048457.

Levin, Jeff. „Faith-Based Initiatives in Health Promotion: History, Challenges, and Current Partnership." American Journal of Health Promotion 28.3 (2014): 139-141.

Magowska, Anita. Zaangażowanie Polaków w misyjna opiekę zdrowotna w Afryce. Poznań: Wydawnictwo Kontekst, 2006.

Medicus Mundi Polonia 4.12/13 (2004): 22-24.

Missoni, Eduardo. Determinants of health and global governance for health. What is at stake? Dostęp 12 sierpnia 2015. <http://www.medicusmundi.org/en/contributions/events/2014/globalhealth-whats-ahead/2014-mini-symposium-missoni.pdf>

Molewska, Joanna. Pawelec, Marta. Wanda Bleńska. Spetnione życie. Poznań: Święty Wojciech, 2011.

Neglected tropical deseases. Dostęp 12 sierpnia 2015.<http://www.who.int/neglected_diseases/diseases/en/> 
Pawłowski, Zbigniew. „Tożsamość katolickich instytucji opieki zdrowotnej na misjach.” Annales Missiologici Posnanienses 14 (2004): 187-197.

Pawłowski, Zbigniew. „Millenium Developmental Goals. [Wybór i tłumaczenie].” Medicus Mundi Polonia 5 (2005) nr 16: 15-16.

Pawłowski, Zbigniew. „Raport Instytutu Misyjnego w Wuerzburgu [streszczenie i tłumaczenie].” Medicus Mundi Polonia 10.34/35 (2010) 15-16.

Pawłowski, Zbigniew. „Światowa Organizacja Zdrowia i opieka medyczna sprawowana przez instytucje religijne w 30 lat po deklaracji w Alma Ata." Annales Missiologici Posnanienses 17 (2010b): 17-23.

Pawłowski, Zbigniew. „Zdrowie dla wszystkich. Idea i rzeczywistość.” Ochrona zdrowia w stosunkach międzynarodowych. Red. Wiesław Lizak, Anna M. Solarz. Warszawa: Wydawnictwo UW, 2013. 35-40.

Pawłowski, Zbigniew, „Ebola! Trudny egzamin z ochrony zdrowia na świecie.” Medicus Mundi Polonia 14.49/50 (2014): 7-9.

Pietraszek, Anna T. Szpital pod niebem. Rozmowy z ojcem Marianem Żelazkiem SVD. Warszawa: Verbinum, 2002.

„Posługa lecznicza Kościoła. Spis tematów.” Medicus Mundi Polonia 14.49/50 (2014): 17.

„Proceedings of the XVII International Conference «The identity of Catholic Health Care Institutions». Vatican, 7-9 Nov. 2002." Dolentium Hominum. Church and health in the world 18.52 (2003).

Widmer, Edgar. „Medicus Mundi International. Istota działania tej organizacji i jej zadania na przyszłość.” Hygeia Public Heath 40.4 (2014): 641-645.

Woy-Wojciechowski, Jerzy. Misjonarze zdrowia. Warszawa: Domena, 2010.

Zbigniew PawŁowski, profesor zw. em. DTMH (Liverpool), dr honoris causa (Uniwersytet Medyczny, Warszawa). Specjalista w chorobach wewnętrznych, pasożytniczych i tropikalnych. Kierownik Kliniki Chorób Pasożytniczych i Tropikalnych UM w Poznaniu (1970-1979 i 1987-1996), szef działu Intestinal Parasitic Infections Światowej Organizacji Zdrowia w Genewie (1979-1986). Członek ośmiu międzynarodowych towarzystw naukowych. Jeden z trzech fundatorów Fundacji Pomocy Humanitarnej Redemptoris Missio w Poznaniu (1992-). 


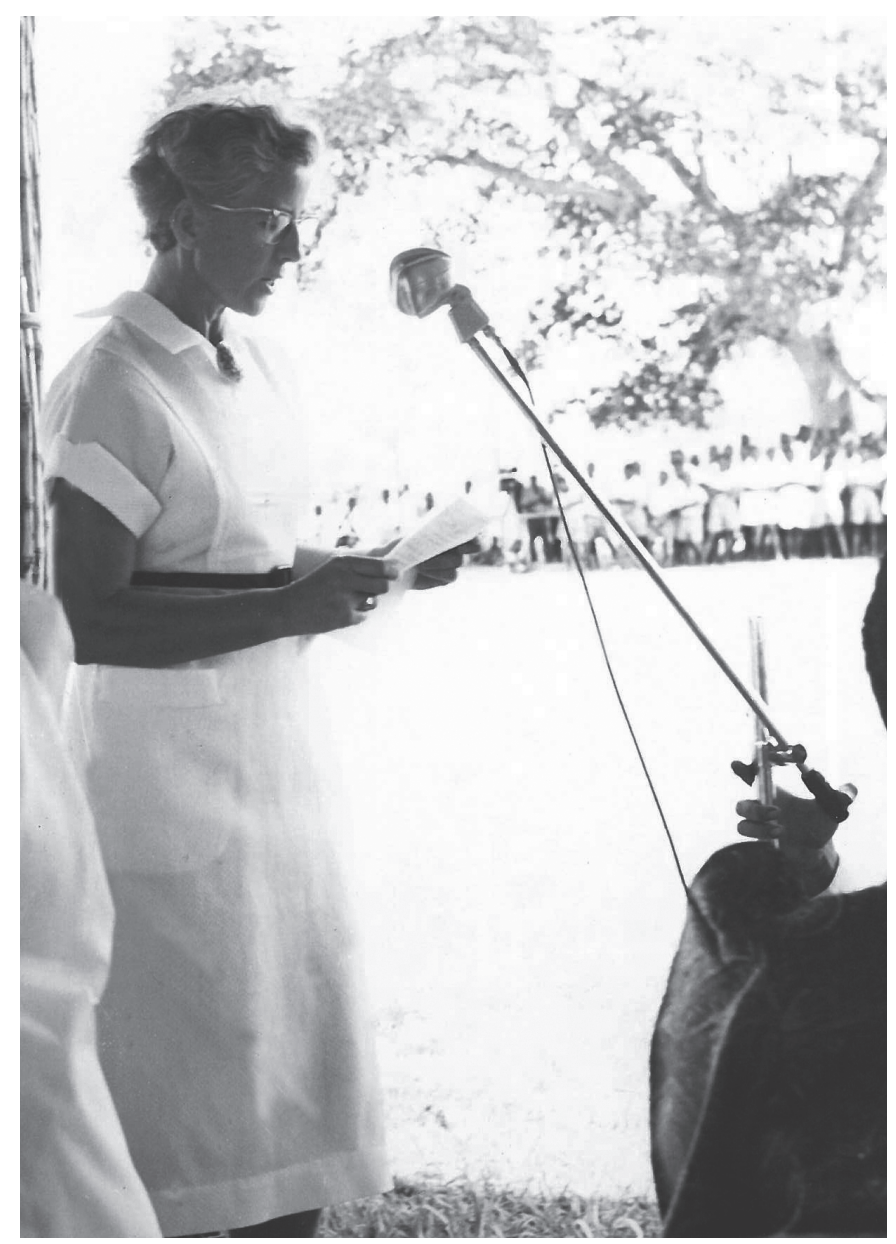

